\title{
Treatments of Eye Diseases in Malay Medical Manuscript Ramuan Obat EAP153/9/4
}

\author{
Mohd Affendi Mohd Shafri*
}

\begin{abstract}
The Malay medical manuscript Ramuan Obat EAP153/9/4 is a Malay medical manuscript from Riau Archipelago in today's Indonesia. It appears to focus on eye diseases and treatments. This study aims to evaluate if the traditional medicines and interventions in the manuscript can be supported scientifically. Critical transliteration and data extraction were performed by applying philological method in identifying and categorising the diseases and interventions. The materia medica was analysed by comparing scientific reports presented in PubMed and Google Scholar, and matching each ingredient to the intended purpose as indicated in the manuscript. The manuscript contains both physical and spiritual interventions amounting to 28 formulations for 7 different types of eye disease. Half of the materia medica and their use in Ramuan Obat EAP153/9/4 could be supported by contemporary scientific evidence. The lack of contemporary scientific evidence for other materia medica, on the other hand, could be attributed to the lack of scientific research on them rather and not necessarily a deficiency in effectiveness. More scientific studies would need to be carried out to validate the safety and efficacy of formulations contained in Malay medical manuscripts as the content could potentially lead to new drug discovery. Apart from scientific gains, the study could also contribute to the preservation of Malay medical culture and heritage.
\end{abstract}

Keywords: Ramuan Obat, Malay medicine, manuscript, Riau, medicine, eye disease

\section{Introduction}

\section{Malay Medical Manuscript}

It is estimated that around 22,000 Malay manuscripts are still extant around the world; 4,000 manuscripts are kept at the Pusat Manuskrip Melayu (Malay Manuscript Centre) of the Perpustakaan Negara Malaysia (National Library of Malaysia), Dewan Bahasa dan Pustaka, University of Malaya, state museums (Johor, Kelantan, Terengganu and Kedah), as well as abroad such as Indonesia (National Museum in Jakarta, and the provincial museums in Acheh, Riau, Medan), Brunei Darussalam, Sri Lanka, and the United States of America, in addition to European countries like France, Belgium, Netherland, German, Russia, England, Spain and Portugal. ${ }^{1}$ Out of these, more than 100 manuscripts are medical manuscripts. ${ }^{2}$

The existence of Malay medical manuscripts allows study of Malay medicine to be re-evaluated. Since the interest in Malay medicine begun in early 70s, source of references for Malay medicine have come from either oral tradition or from colonial sources. Malay medical manuscripts preserve the original perspectives of Malay practitioners over several centuries, hailing from various corners of the Malay World, thus is more representative and have a clear edge against oral tradition and colonial sources. Thousands of formulations, fruits of laborious works and keen observations, are contained in the manuscripts most of which are hitherto unknown to modern world.

The utility of studying old medical manuscript is exemplified recently by Youyou Tu, who won the Nobel Prize for Medicine in 2015 for her breakthrough discovery of antimalarial drug called artemisinin. Youyou Tu studied ancient Chinese herbal formulation and found an effective formulation in a manuscript entitled Zhou Hou Bei Ji Fang, 'A Handbook of Prescriptions for Emergencies,' which was written by Ge Hong circa 284-346 CE. ${ }^{3}$ In similar vein, by applying the concept of ethno-medicine and ethno-pharmacology in studying the Malay medical manuscript, the huge prospect of modern drug

\footnotetext{
* Mohd Affendi Mohd Shafri (PhD), Associate Professor, Kulliyyah of Allied Health Sciences, International Islamic University Malaysia, Gombak, Selangor, Malaysia. Email: affendishafri@iium.edu.my.

${ }^{1}$ Harun Mat Piah (2015), "Ilmu Perubatan Melayu Tradisional dari Naskhah-Naskhah Lama," Jurnal Antarabangsa Alam Dan Tamadun Melayu, Vol. 3, No. 3, pp. 3-17.

${ }^{2}$ Mohd Affendi Mohd Shafri (2019), Sari Segala Ubat, Kuala Lumpur: Akademi Jawi Malaysia Sdn Bhd, p. 3.

3 Tu, Y. (2011), "The discovery of artemisinin (qinghaosu) and gifts from Chinese medicine," Nature Medicine, Vol. 17, No. 10, pp. 12171220 .
} 
innovation and drug discovery as well as preserving the Malay heritage and traditional Malay medicine knowledge can be explored.

With regards to Malay medical manuscript study, several of the Malay medical manuscripts have been transliterated and published as full volumes. These include MSS2515, ${ }^{4}$ Kitab Tib Muzium Terengganu, ${ }^{5}$ MSS1292, ${ }^{6}$ MSS2999, ${ }^{7}$ Tayyib al-Ihsan, ${ }^{8}$ al-Rahmah fi al-Tibb, ${ }^{9}$ Rumah Ubat di Pulau Penyengat, ${ }^{10}$ and MSS B $15 .{ }^{11}$ Several researchers have made analysis of these manuscripts from the perspective of language. ${ }^{12}$ Increasingly, Malay medical manuscripts are now also studied under specific medical themes such as dermatology ${ }^{13}$ and parasitology. ${ }^{14}$ The manuscript Ramuan Obat EAP153/9/4, as an intact volume comprising only one type of disease, namely eye diseases, allows discussion on a topic which has not yet been discussed previously from the perspective of Malay medical manuscripts.

\section{Background of Manuscript}

Ramuan Obat EAP153/9/4 is sourced from Riau, one of the regions in the Malay Archipelago that has vast collections of manuscripts, including medical manuscripts. ${ }^{15}$ The medical manuscripts there form part of the individual or institutional collections such as Balai Maklumat Kebudayaan Melayu Riau and Linggam Cahaya Museum in Daik, Pulau Lingga. Most of these manuscripts had been digitalised under the supervision of British Library in a project called the 'Endangered Archive Project (EAP).' ${ }^{16}$

The manuscript Ramuan Obat EAP153/9/4 from Riau is selected as more than $80 \%$ of its content is medical. It is originally from the personal collection of the late Raja Syu'ib bin Raja Muhamad Zein which is now kept by his son Raja Muhammad Abdullozan. It was digitized under the British Library's Endangered Archive Project (EAP) during Raja Syu'ib's permission. The information regarding the origin of the manuscript as well as the digital images of the manuscript can be read and accessed online at EAP's website: https://eap.bl.uk/archive-file/EAP153-9-4. Thus, images from the manuscript are not included in this article. The use of this manuscript for research and publication has also been granted approval by the current owner, Raja Muhammad Abdullozan, via personal communication.

Ramuan Obat EAP153/9/4 contains treatment for the eyes exclusively and has not been studied previously. The manuscript consists of 12 pages of a blue-ruled exercise book with loose binding and no covers. The manuscript is estimated to come from late 19 th century or early $20^{\text {th }}$ century. 7 pages are fully written whereas other pages are empty or have scribblings. The first written page contains explanation of Basmalah and is not presented in this article.

\section{Methodology}

The methods of transliteration, data extraction and comparative analysis with contemporary scientific reports follow the method outlined and applied by Mohd Affendi (2019). ${ }^{17}$

\footnotetext{
${ }^{4}$ Harun Mat Piah and Zawiyah Baba (2014), Kitab Tib MSS2515, Bangi: Penerbit UKM.

5 Harun Mat Piah (2017), Kitab Tib Muzium Terengganu, Kuala Lumpur: Institut Penyelidikan Perhutanan Malaysia.

${ }^{6}$ Harun Mat Piah and Nik Musa'adah Mustapha (2019), Kitab Tib MSS1292, Kuala Lumpur: Institut Penyelidikan Perhutanan Malaysia.

7 Abdul Ghani Hussain (2015), MSS2999 Kitab Tib: Pandangan dan Tafsiran Perubatan Moden Terhadap Manuskrip Perubatan Melayu, Kuala Lumpur: Institut Penyelidikan Perhutanan Malaysia.

8 Mohd Affendi Mohd Shafri (2015), Tayyib al-Ihsan fi al-Tibb al-Insan, Kuala Lumpur: Akademi Jawi Malaysia.

9 Mohd Affendi Mohd Shafri (2017), al-Rahmah fi al-Tib wa al-Hikmah, Kuala Lumpur: Akademi Jawi Malaysia.

${ }_{10}$ Mohd Affendi Mohd Shafri (2018), Rumah Ubat Di Pulau Penyengat, Kuala Lumpur: Akademi Jawi Malaysia.

11 Mohd Affendi, Sari Segala Ubat.

12 Ab. Razak Abdul Karim (2006), Analisis Bahasa Dalam Kitab Tib Pontianak, Kuala Lumpur: Dewan Bahasa dan Pustaka; Indirawati Zahid, Ab Razak Ab Karim and Rohaidah Haron (2019), "Kata Kerja dan Komunikasi Berkesan Dalam Kitab Tib Muzium Terengganu dan Huraian Teks," Bitara: International Journal of Civilisational Studies and Human Sciences, Vol. 2, No. 4, $27-42$.

13 Abdul Ghani Hussain (2019), Dermatologi Dalam Kitab Tib Muzium Terengganu, Kuala Lumpur: Institut Penyelidikan Perhutanan Malaysia.

${ }^{14}$ Muhammad Widus Sempo, Nazariah Yahya, Malki Ahmad Nasir and Mohd Azmi Mohd Razif (2020), Rawatan Sakit Cacingan dalam Manuskrip Perubatan Melayu, Kuala Lumpur: Penerbit USIM.

15 Harun Mat Piah and Zawiyah Baba (2014), Kitab Tib MSS2515.

16 Mohd Affendi, Rumah Ubat Di Pulau Penyengat.

17 Mohd Affendi, Sari Segala Ubat.
} 
Transliteration of the Manuscript

To transliterate the manuscript, a critical transliteration was performed by transliterating the text wordby-word together while correcting spelling and grammatical errors as well as inserting transliterator's interpretation of the text. Formulation number is given to each formulation in the manuscript in the format of 153/9/4/FXXX, for which:

153/9/4 denotes the accession number of the manuscript,

$\mathrm{F}$ denotes 'formulation'

$\mathrm{XXX}$ denotes the sequence number of a formulation.

References were made to established database such as Pusat Rujukan Persuratan Melayu (https://prpm.dbp.gov.my/) and publications such as A Dictionary of Malayan Medicine. ${ }^{18}$

\section{Data Extraction and Classification}

The data extraction process was performed by extracting data according to the types of materials (e.g. plant-based, animal-based and miscellaneous) and alphabetical order following the vernacular name of the materials. The scientific name, formulation number, and parts of the materials used are also included.

\section{Comparative Analysis of the Content of the Manuscript to Contemporary Scientific Reports}

Comparative analysis is a method in which use of individual herbal or animal or mineral in a traditional formulation in a text is compared to published papers in modern scientific databases. The presence of papers of related use or in support of the use in the manuscripts is an indication of verified use. However, the absence of the papers does not necessarily mean that the traditional use is unverified as many of the traditional Malay formulations, or even the individual ingredients from the Malay world, have not been studied by modern scientists. The sources of the modern scientific literature include PubMed and Google Scholar because both search engines are considered as useful clinical and biomedical-evidence search tools. While PubMed only retrieves peer-reviewed journal articles, Google Scholar on the other hand retrieves both peer-reviewed and non-peer-reviewed articles from vast range of medical subdisciplines. The scientific evidence search strategy used in this study, used together with Boolean Operator, include:

a. In vitro study OR In/ex vivo study OR Animal study OR Randomised controlled trial study OR human case study.

b. Any parts of the materia medica that is used in the clinical study.

The search strategy was established to ensure that the scientific evidence retrieved for any materia medica is reliable and relevant.

\section{Results and Analysis}

The transliteration and translation of Ramuan Obat EAP153/9/4 is provided here:

153/9/4/F001 (The earlier page(s) appears missing.) Afyun yang baik maka asah pada besi beri air limau kapas atau minyak lenga maka sapukan pada kelopak mata di luar jua.

Meaning: Ground opium of good quality on steel surface with the juice of cotton citron or sesame oil and smear onto the external part of the eyelid.

153/9/4/F002 Sebagai lagi ambil garam sedikit maka bacakan Qūl huwa Allāhū Āhad maka disapukan pada kelopak mata.

Meaning: Take a bit of salt and recite هُلْ هُو اللَُّ أَحَد then rub on the eyelid.

153/9/4/F003 Sebagai lagi disurat pada mangkuk sabun maka taruh semalam maka bubuh air esok hari maka dititikkan pada mata inilah yang disuratkan:

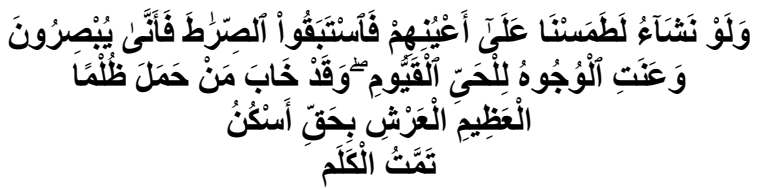

\footnotetext{
18 John D. Gimlette and H.W. Thomson (1939), A Dictionary of Malayan Medicine, London: Oxford University Press.
} 
Meaning: Write on a white bowl,

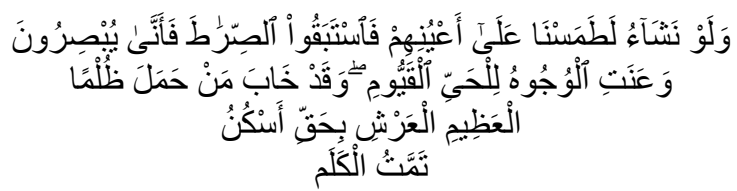

leave it to sit overnight before filling the bowl with water the following day and as eyedrop.

153/9/4/F004 Ini ubat mata kabur berselaput atau tumbuh dagingan-dagingan maka ambil buah kelor dan akar keremak dan ibu kunyit kemudian ambil parang puting maka bakar semuanya (se)telah itu diasah dengan buah pala dan air limau nipis maka sapukan kepada mata kangkangkan biar sampai masuk sedikit-sedikit ke dalam mata ā fìyāt adanya.

This is the remedy for dimness of vision with cataract or pterygium. Take fruits of moringa, roots of keremak and the rhizome of turmeric. Burn the items on a piece of dulled machete and mix with nutmeg and key lime juice. Rub on the eyelid, let it seep into the eye bit by bit.

153/9/4/F005 Sebagai la(gi) ubat mata kabur maka ambil daun sirih yang kuning tiga helai ramas biar halus-halus maka ambil airnya dan bubuh sepang dan kayu arang kemudian tapis, bubuh bunga melur campurkan maka bacakan surah al-Ikhläṣ tiga kali senafas maka titikkan ke dalam mata ā'fìyāt adanya.

Meaning: Another remedy for dimness of vision, take yellow betel-pepper leaves, knead to fine texture and collect its juice then insert with sappanwood and charcoal. Strain, add jasmine flower and recite surah al-Ikhlās three times in one breath and use the mixture as eyedrop.

153/9/4/F006 Sebagai lagi ubat mata kabur ambil pucuk budi tujuh helai dan gula batu sedikit maka digiling diperahkan pada mata adanya.

Meaning: Another remedy for dimness of vision. Take seven shoots of pucuk budi and rock sugar, grind the ingredients and use as eyedrop.

153/9/4/F007 Sebagai lagi ubat mata kabur maka apabila ada merah-merah matanya lagi kering lakunya di dalam kedua matanya dan kering mukanya alamat bertambah penyakit sawdāwē dan safrāwī̄ maka ambil isi asam jawa yang kuning-kuning kemudian ramas dengan air kemudian bubuh pada perca putih maka tampalkan pada mata dan muka lalu dibawa tidur kerjakan tiap-tiap hari maka inilah jampinya:

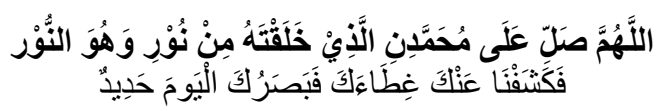

Meaning: Another remedy for dimness of vision and when there is redness and dryness in the eyes, and dryness on the face, indicating bilious and liver problems. Take the yellow marrow of tamarind and squeeze with water, put on a white cloth and use as eyepatch when sleeping. Do every day together with this prayer:

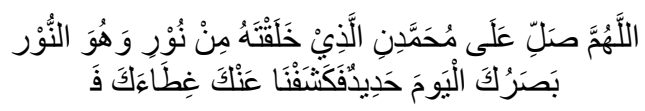

153/9/4/F008 Sebagai lagi jampinya tatkala di dalam mengambil air sembahyang maka simbahkan kepada mata maka baca șelawat ini:

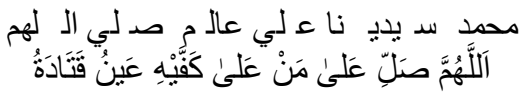

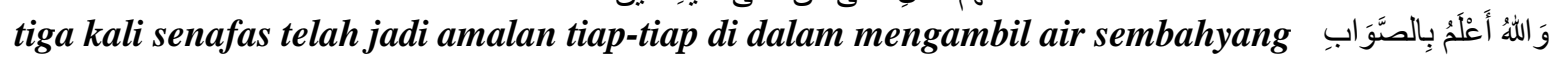

Meaning: Another the prayer to be recited when performing the ablution by splashing on the eyes:

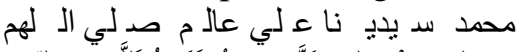

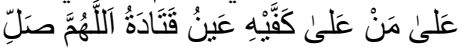

Read three times in one breath. Recited everytime when performing ablution.

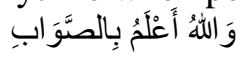


153/9/4/F009 Sebagai lagi ubat mata kabur atau berselaput maka ambil hempedu kambing dan masukkan lada sulah tujuh butir ke dalam hempedu itu maka ikat baik-baik maka gantung pada tulang bumbungan rumah betul sama tengah rumah itu apabila sampai tujuh hari ambil lada sulah itu sebutir pirik lumat-lumat beri air sedikit maka titikkan pada mata itu pagi dan petang sebutir sehari dan mandinya dua kali sehari hingga tujuh hari mujarāb.

Meaning: Another remedy for dimness of vison or cataract. Fill in goat's bile with seven black (also known as white) pepper seeds are to be, neatly tied and placed at the center of house ridge for seven days. One black pepper seed is to be crushed with water and used as eyedrop. This is to be performed one seed a day, both morning and evening and shower twice a day until day seven.

153/9/4/F010 Sebagai lagi ubat mata kabur ambil limau kerbau kupas kulitnya belah tiga bubuh garam tiga buku maka rebus setelah masak maka embunkan kemudian pagi-pagi basuhkan pada mata biar masuk pada mata itu sedikit jika berselaput sekalipun baik juga, insya Allāh Ta'ālä mujarāb.

Meaning: Another remedy for dimness of vision. Buffalo eye citron is to be peeled and cut into three pieces and mixed with three pieces of coarse salt. The mixture is boiled and be left overnight outside. The mixture is to be used as eyewash in the morning.

153/9/4/F011 Sebagai lagi ubat kabur mata ambil daun penaga tiga puluh helai yang baik jangan cacat maka surat alif tiga puluh satu huruf satu helai maka rebus barang tiga kali mendidih bangkit sejukkan pada pinggan putih rendamkan mukanya ke dalam pinggan serta bukakan matanya sekali, $\bar{a}$ 'füāt adanya.

Meaning: Another remedy for dimness of vision. 30 pieces of penaga leaves that are not torn or damaged are to be taken and inscribed with 31 alif alphabet per leaf. The ingredients are boiled then cooled three times in a white bowl. The face should be dipped in the mixture with eyes opened.

153/9/4/F012 Sebagai lagi ubat mata kabur ambil daun merpoyan tumbuk lumat-lumat maka bubuh kepada perca putih maka perahkan kepada mata ā' fì̄ât adanya.

Meaning: Another remedy for dimness of vision. Merpoyan leaves is to be pounded into smooth texture, put onto white cloth and squeezed and used as eyedrop.

153/9/4/F013 Sebagai lagi ubat sakit mata tumbuh maka ambil ara tanah maka patahkan batangnya ambil getahnya cucuhkan kepada mata, $\bar{a}$ fìyāt adanya.

Meaning: Another remedy for chalazion. Stem of ara tanah is broken to get the sap and used as eyedrop.

153/9/4/F014 Sebagai lagi ubat mata tumbuh maka ambil sepang dan tawas sedikit kemudian asah dengan air maka titikkan kepada mata, à'fìyät adanya.

Meaning: Another remedy for chalazion. Sepang and potassium alum are rubbed down with water on hard surface and used as eyedrop.

153/9/4/F015 Sebagai lagi ubat (mata) tumbuh maka ambil akar kelumpang dikerat-kerat ditadah ambil airnya maka pagi-pagi titikkan kepada mata yang sakit itu, $\bar{a}$ fì̀āt adanya.

Meaning: Another remedy for chalazion. Kelumpang roots are cut into pieces to obtain the sap and be used as eyedrop in the morning.

153/9/4/F016 Sebagai lagi ubat mata jua jika sudah tumbuh maka ambil bulu ayam hitam maka cucuhkan kepada mata yang tumbuh itu inilah tawarkan kepada bulu ayam itu atau kepada mata Meaning: Another remedy for chalazion. Feather of black chicken is touched to the affected eye.

153/9/4/F017 Dan daging lembu dan cabai, ertinya campli, dan ursi dan terung dan bermula yang menambah cahaya mata segala makanan yang manis-manis adanya.

Meaning: Beef, long pepper, ursi and eggplant or sweet food are materials that enhance eyesight.

153/9/4/F018 Sebagai lagi ambil buah kelumpang maka tunu ambil abunya maka ditiris maka dijadi akan garam maka ambil pijar dan kasturi maka dipercelakkan ketiganya pada matanya sapar itu adanya.

Meaning: Kelumpang fruits are roasted and crushed into powder. The powder is then mixed with pijar and musk and used as eyeliner for unclear vision. 
153/9/4/F019 Sebagai lagi ambil daun bilang-bilang papan dan cuka masam maka diperahkan ke dalam mata.

Meaning: Leaves of bilang-bilang papan and sour vinegar are squeezed and used as eyedrop.

153/9/4/F020 Sebagai lagi ambil buah anjan-anjan putih dan daunnya maka dipipis lumat-lumat dipercelak pada mata adanya.

Meaning: White anjan- anjan fruit and leaf are pounded into smooth texture and used as eyeliner.

153/9/4/F021 Sebagai lagi ambil biji bayam diasahkan akan airnya air mawar dicampurkan dengan paji maka dipercelak mata nescaya terang insyā Allāh Ta'älā.

Meaning: Spinach seed is rubbed onto hard surface with rose water and mixed with paji. The mixture is used as eyeliner.

153/9/4 F022 Sebagai lagi ubat mata daging-dagingan ambil akar anjan-anjan putih dan bunganya dan daunnya dan kulitnya maka pipis lumat-lumat maka bubuh paji sedikit akan airnya cuka masam maka bubuh pada perca nipis maka perahkan pada mata.

Meaning: Another remedy for pterygium. White anjan-anjan roots, flowers, leaves and bark are pounded into smooth texture and mixed with paji and sour vinegar. The mixture is put onto white cloth and used as eyedrop.

153/9/4/F023 Sebagai lagi ambil akar perupuk diasah pada batu akan airnya air madu adapun bunganya yang putih itu dikeluskan perahkan pada mata.

Meaning: Perupuk roots are rubbed onto hard surface with honey. The mixture is then rubbed mildly with the white flower of perupuk and used as eyedrop.

153/9/4/F024 Sebagai lagi ambil khulanjan maka diasah akan airnya air susu orang belum bergigi maka perahkan pada mata.

Meaning: Galangal is rubbed onto hard surface with milk and used as eyedrop.

153/9/4/F025 Dan sebagai lagi ambil keremak betina dikeluskan perahkan kepada mata.

Meaning: Keremak betina is rubbed mildly and used as eyedrop.

153/9/4/F026 Sebagai lagi minyak lenga dipakai dengan air limau kapas dibubuhkan pada kelopak mata.

Meaning: Sesame oil with cotton citron juice is used together on eyelid.

153/9/4/F027 Sebagai lagi ubat mata daging-dagingan ambil kulit pinang kelat maka tunu ambil abunya maka diheningkan maka dibubuh pada kapas perahkan pada mata.

Meaning: Another remedy for pterygium. Bitter betelnut peel is roasted and its ashes is left cooled and put on cotton before being used as eyeliner.

153/9/4/F028 Sebagai lagi ubat mata sapar atau daging-dagingan ambil bunga pekan seratus dua puluh tangkai, bunga lenga lima puluh tangkai, lada sulah enam belas biji, cabai lima puluh biji, beras Kedah lima puluh biji, bittikh lima puluh biji, bawang tujuh hulas, kacang hitam tujuh biji, mata kunyit tujuh mata, sirih bertemu urat tiga helai, surat du'a ini:

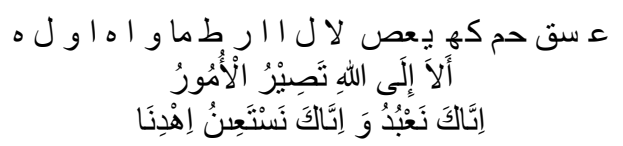

Maka pipis dengan air jernih maka geliga jemur kering-kering.

Dan jika mata sakit air susu akan airnya di asah maka diperah ubat itu ke dalam mata; dan jika mata sapar malam akan airnya kemih jika pada malam; adapun jika pada siang sapar akan airnya air embun; dan jika mata daging-dagingan akan airnya air mawar; dan jika mata bilis airnya air pinang muda adanya; dan jika hidung berbau busuk airnya air limau kapas muda; dan jika barah airnya sirih akan airnya; dan jika puru ketut akan airnya sarang limau kapas di asah maka palitkan pada luka ia; dan jika panau jahat minyak sempelah akan airnya maka dipersusuk pada segala 
tubuh; jika فو ول airnya air terung perat akan airnya diasah maka diperahkan pada ke dalam telinga; dan jika dikerit ular air susu akan airnya; dan jika kena racun airnya mentimun pahit akan airnya maka diminum; dan jika batuk air pisang habu akan airnya; dan jika pitam air mangkuk di masak akan airnya; dan jika هثوران air lemak hayam akan airnya; dan jika ngilu ketik daun sudu masak akan airnya; jika keteriakan air habu biji kapas akan airnya; jika busuk air buah pisang akan airnya, wallahu a'lam.

Meaning: Another remedy for unclear vision and pterygium. Take one hundred and twenty pekan flowers, fifty sesame flowers, sixteen pepper seeds, fifty chilly seeds, fifty kernels of rice of Kedah type, fifty seeds of watermelon, seven cloves of onions, seven seeds of black turtle beans, seven stem buds of turmeric, and seven betel-pepper leaves with side-veins arching back into the midrib. On the betelpepper leaves write the prayer:

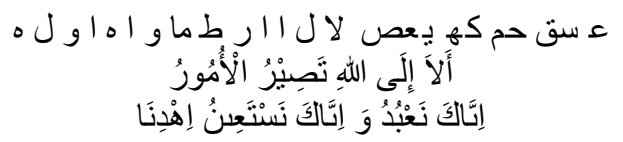

Then, grind with a rolling stone on a spice-block with clear water, make into beads and leave to dry.

To use this formulation for other diseases, the clear water can be replaced accordingly: (i) for sore eye, replace with milk; (ii) for night blindness (nyctalopia), replace with urine; (iii) for day blindness (hemeralopia), replace with morning dew; (iv) for pterygium, replace with rose water; (v) for bleareyed problems, replace with extracts from unripe areca nut; (vii) for sinusitis, use juice of cotton citron; (viii) for cancer or chronic wound, use betel juice; (ix) for certain type of yaws which cause great itchiness, replace with juice from the peel of cotton citron and salve on the scurf or wound; (x) for ringworm infection, replace with minyak sempelah and apply all over the body; (xi) for g ف (a type of unidentified problem), use the juice of black nightshade and squeeze into the ears; (xii) for snake-bites, use milk; (xiii) if poisoned, use juice of cucumber and drink; (xiv) for cough, replace with juice of pisang abu; (xv) for fainting, use boiled water which has become cool in a bowl; (xvi) for (an unknown problem), use the extract from chicken fat; (xvii) for neuralgic headache, pick some sudu leaves and boil for its extract; (xviii) for hysterical symptoms, use the water mixed with ashes of cotton seeds; and finally (xix) for busuk, or putrid smell coming from the body, use banana juice. And God knows best.

\section{Data Extraction and Classification of Ramuan Obat EAP153/9/4 Content}

\section{Classification of Eye Diseases}

The transliteration of the text, Ramuan Obat EAP153/9/4, showed a number of eye diseases that include mata kabur (dimness of vision), mata berselaput (cataract), mata tumbuh (chalazion), daging-dagingan (pterygium), mata sapar (unclear vision including the night blindness (nyctalopia) and day blindess (hemeralopia)), mata merah (red eye), mata kering (dry eye), mata bilis/bilas (bleary or watery eye) dan mata gatal (itchiness of the eye), mata sakit (sore eyes) and unspecified eye disease. A total of 28 formulations are identified based on the transliteration of the text of Ramuan Obat EAP153/9/4. One formulation, code named 153/9/4/F028, can be used for several types of eye and non-eye diseases.

The formulations are sorted according to its use (Table 1) and the category of the formulation (Table 2). The non-eye complaints related to 153/9/4/F028 is not included in the interest of keeping the integrity of the results to eye diseases.

Table 1. Eye Diseases and Formulation Number in Ramuan Obat EAP153/9/4

\begin{tabular}{lll}
\hline Malay Vernacular Name & $\begin{array}{l}\text { Probable Modern Scientific } \\
\text { Name }\end{array}$ & $\begin{array}{l}\text { Formulation Number } \\
\mathbf{( 1 5 3 / 9 / 4 / F 0 x x )}\end{array}$ \\
\hline Mata kabur & Dimness of vision & $153 / 9 / 4 F 004$ \\
& $153 / 9 / 4 \mathrm{~F} 005$ \\
& $153 / 9 / 4 \mathrm{~F} 006$ \\
& $153 / 9 / 4 \mathrm{~F} 007$ \\
& $153 / 9 / 4 \mathrm{~F} 009$ \\
& $153 / 9 / 4 \mathrm{~F} 010$
\end{tabular}




\begin{tabular}{|c|c|c|}
\hline & & 153/9/4F011 \\
\hline & & 153/9/4F012 \\
\hline \multirow[t]{2}{*}{ Mata berselaput } & Cataract & 153/9/4F004 \\
\hline & & 153/9/4F009 \\
\hline \multirow[t]{4}{*}{ Mata tumbuh } & Chalazion & 153/9/4F004 \\
\hline & & $153 / 9 / 4 \mathrm{~F} 014$ \\
\hline & & $153 / 9 / 4 \mathrm{~F} 015$ \\
\hline & & $153 / 9 / 4 \mathrm{~F} 016$ \\
\hline \multirow[t]{4}{*}{ Daging-dagingan } & Pterygium & 153/9/4F004 \\
\hline & & $153 / 9 / 4 F 022$ \\
\hline & & $153 / 9 / 4 \mathrm{~F} 027$ \\
\hline & & $153 / 9 / 4 / F 028$ \\
\hline \multirow[t]{2}{*}{ Mata sapar } & Unclear vision & $153 / 9 / 4 F 018$ \\
\hline & & $153 / 9 / 4 / \mathrm{F} 028$ \\
\hline Mata merah, kering dan gatal & $\begin{array}{l}\text { Inflamed eye (red eye, dry } \\
\text { eye, itchy eye) }\end{array}$ & $153 / 9 / 4 \mathrm{~F} 007$ \\
\hline Mata sakit & Eye sore & 153/9/4/F028 \\
\hline Mata bilis/bilas & Bleary or watery eye & $153 / 9 / 4 / \mathrm{F} 028$ \\
\hline \multirow[t]{12}{*}{ Unspecified eye disease } & N/A & $153 / 9 / 4 \mathrm{~F} 001$ \\
\hline & & 153/9/4F002 \\
\hline & & $153 / 9 / 4 \mathrm{~F} 003$ \\
\hline & & 153/9/4F008 \\
\hline & & 153/9/4F017 \\
\hline & & 153/9/4F019 \\
\hline & & 153/9/4F020 \\
\hline & & $153 / 9 / 4 F 021$ \\
\hline & & $153 / 9 / 4 F 023$ \\
\hline & & $153 / 9 / 4 \mathrm{~F} 024$ \\
\hline & & $153 / 9 / 4 \mathrm{~F} 025$ \\
\hline & & $153 / 9 / 4 \mathrm{~F} 026$ \\
\hline
\end{tabular}

Table 2. Category and Number of Formulations Identified in Ramuan Obat EAP153/9/4

\begin{tabular}{ll}
\hline Category of Formulation & Number of Formulation(s) \\
\hline Herbs or Materials Only & 20 \\
Herbs or Materials Supported by Prayer & 5 \\
& 2 \\
Prayer Only & 1 \\
Incomplete & \\
\hline
\end{tabular}

\section{Classification of Materials}

Based on the transliteration of the text of Ramuan Obat EAP153/9/4 manuscript, a total of 51 individual materials have been identified. These materials could further be divided into 3 categories namely plantbased materials, animal-based materials and others. The materials are arranged alphabetically according to their respective vernacular names along with their scientific names (if applicable) in Table 3, Table 4 and Table 5.

A. Plant-Based Materials

Table 3. The List of Identified Plant-Based Materials

\begin{tabular}{|c|c|c|c|}
\hline $\begin{array}{l}\text { Vernacular } \\
\text { Name }\end{array}$ & Scientific Name & $\begin{array}{l}\text { Formulation } \\
\text { Number } \\
(153 / 9 / 4 / F 0 x x)\end{array}$ & Parts Used \\
\hline Afyun (Poppy) & Papaver somniferum & 153/9/4/F001 & $\begin{array}{l}\text { Not stated; normally } \\
\text { the seed }\end{array}$ \\
\hline Akar keremak & Ipomea digitata & 153/9/4/F004 & Root \\
\hline $\begin{array}{l}\text { Anjan-anjan } \\
\text { (putih) }\end{array}$ & $\begin{array}{l}\text { Memecyclon } \\
\text { umbellatum }\end{array}$ & 153/9/4/F020 & $\begin{array}{l}\text { Leaf } \\
\text { Fruit }\end{array}$ \\
\hline
\end{tabular}




\begin{tabular}{|c|c|c|c|}
\hline & & 153/9/4/F022 & $\begin{array}{l}\text { Root } \\
\text { Flower } \\
\text { Leaf } \\
\text { Bark }\end{array}$ \\
\hline Ara tanah & Euphorbia hirta & 153/9/4/F013 & Stem latex \\
\hline $\begin{array}{l}\text { Asam jawa } \\
\text { (Tamarind) }\end{array}$ & Tamarindus indica & 153/9/4/F007 & Fruit/flesh \\
\hline Bawang & Allium spp. & 153/9/4/F028 & Bulb \\
\hline $\begin{array}{l}\text { Bayam } \\
\text { (Spinach) }\end{array}$ & Amaranthus spp. & 153/9/4/F021 & Seed \\
\hline Beras (Kedah) & Oryza sativa & 153/9/4/F028 & Seed (grain) \\
\hline Bilang-bilang & $\begin{array}{l}\text { Sesuvium } \\
\text { portulacastrum }\end{array}$ & 153/9/4/F019 & Leaf \\
\hline $\begin{array}{l}\text { Bittikh } \\
\text { (Watermelon) }\end{array}$ & Citrullus vulgaris & 153/9/4/F028 & Fruit \\
\hline $\begin{array}{l}\text { Buah pala } \\
\text { (Nutmeg) }\end{array}$ & Myristica fragrans & 153/9/4/F004 & Fruit \\
\hline Cabai & Piper longum & $\begin{array}{l}\text { 153/9/4/F017 } \\
\text { 153/9/4/F017 }\end{array}$ & $\begin{array}{l}\text { Fruit } \\
\text { Fruit }\end{array}$ \\
\hline Kacang hitam & Phaseolus vulgaris & $153 / 9 / 4 / F 028$ & Seed \\
\hline Kelor & Moringa oleifera & 153/9/4/F004 & Fruit \\
\hline Kelumpang & Sterculia foetida & $\begin{array}{l}\text { 153/9/4/F015 } \\
153 / 9 / 4 / F 018\end{array}$ & $\begin{array}{l}\text { Root } \\
\text { Root }\end{array}$ \\
\hline Keremak betina & Eclipta alba hassk & $153 / 9 / 4 / F 025$ & \\
\hline $\begin{array}{l}\text { Khulanjan } \\
\text { (Galangal) }\end{array}$ & Alpinia galangal & 153/9/4/F024 & Root \\
\hline $\begin{array}{l}\text { Kunyit } \\
\text { (Turmeric) }\end{array}$ & Curcuma longa & $\begin{array}{l}153 / 9 / 4 / F 004 \\
153 / 9 / 4 / F 028\end{array}$ & $\begin{array}{l}\text { Rhizome } \\
\text { Stem bud }\end{array}$ \\
\hline $\begin{array}{l}\text { Lada sulah } \\
\text { (Black pepper) }\end{array}$ & Piper nigrum & $\begin{array}{l}\text { 153/9/4/F009 } \\
153 / 9 / 4 / F 028\end{array}$ & $\begin{array}{l}\text { Seed (peppercorn) } \\
\text { Seed (peppercorn) }\end{array}$ \\
\hline Lenga & Sesamum indicum & $\begin{array}{l}153 / 9 / 4 / \mathrm{F} 001 \\
153 / 9 / 4 / \mathrm{F} 026 \\
153 / 9 / 4 / \mathrm{F} 028\end{array}$ & $\begin{array}{l}\text { Oil } \\
\text { Oil } \\
\text { Flower }\end{array}$ \\
\hline $\begin{array}{l}\text { Limau kapas } \\
\text { (Cotton citron) }\end{array}$ & Citrus aurantifolia & $\begin{array}{l}153 / 9 / 4 / F 001 \\
153 / 9 / 4 / F 026\end{array}$ & $\begin{array}{l}\text { Juice, from fruit } \\
\text { Juice, from fruit }\end{array}$ \\
\hline $\begin{array}{lr}\text { Limau } & \text { kerbau } \\
\text { (Buffalo } & \text { eye } \\
\text { citron) } & \end{array}$ & Citrus medica & 153/9/4/F010 & Fruit peel \\
\hline $\begin{array}{l}\text { Limau nipis } \\
\text { (Key lime) }\end{array}$ & Citrus $\times$ aurantiifolia & 153/9/4/F004 & Juice, from fruit \\
\hline Marapoyan & Rhodennia cinerea & 153/9/4/F012 & Leaf \\
\hline Mawar (Rose) & Rosa spp. & 153/9/4/F021 & $\begin{array}{l}\text { Flower extract or } \\
\text { juice (air bunga) }\end{array}$ \\
\hline $\begin{array}{l}\text { Melur (Jasmine) } \\
\text { Paji or kapur }\end{array}$ & $\begin{array}{l}\text { Jasminium sambac } \\
\text { Drybalanops lanceolata } \\
\text { or D. Aromatic }\end{array}$ & $\begin{array}{l}153 / 9 / 4 / F 005 \\
153 / 9 / 4 / F 021 \\
153 / 9 / 4 / F 022\end{array}$ & $\begin{array}{l}\text { Flower } \\
\text { Powder }\end{array}$ \\
\hline Pekan & Jasminium curtisii & 153/9/4/F028 & Flower \\
\hline
\end{tabular}




\begin{tabular}{|c|c|c|c|}
\hline Penaga & Mesua ferrea $L$. & 153/9/4/F011 & Leaf \\
\hline Peropok & Hemigyrosa longifolia & 153/9/4/F023 & Root \\
\hline \multirow{6}{*}{$\begin{array}{l}\text { Pinang } \\
\text { (Betelnut) } \\
\text { Pucuk budi } \\
\text { Mawar } \\
\text { Sepang }\end{array}$} & \multirow[t]{2}{*}{ Areca catechu } & $153 / 9 / 4 / F 027$ & Fruit peel \\
\hline & & $153 / 9 / 4 / F 028$ & Unripe fruit \\
\hline & Ficus benjamina & $153 / 9 / 4 / F 006$ & Shoot \\
\hline & Rosa spp. & $153 / 9 / 4 / F 028$ & Flower (rosewater) \\
\hline & Caesalpinia sappan & 153/9/4/F005 & $\begin{array}{l}\text { Not stated (most } \\
\text { likely the bark) }\end{array}$ \\
\hline & & 153/9/4/F014 & $\begin{array}{l}\text { Not stated (most } \\
\text { likely the bark) }\end{array}$ \\
\hline \multirow[t]{2}{*}{ Sirih (Betel) } & \multirow[t]{2}{*}{ Piper betle } & 153/9/4/F005 & Leaf \\
\hline & & $153 / 9 / 4 / F 028$ & $\begin{array}{l}\text { Leaf with side-veins } \\
\text { arching to midrib }\end{array}$ \\
\hline \multirow{2}{*}{$\begin{array}{l}\text { Terung } \\
\text { (Eggplant) } \\
\text { Ursi }\end{array}$} & Solanum spp & 153/9/4/F017 & Fruit \\
\hline & Unidentified & 153/9/4/F017 & $\begin{array}{l}\text { Not stated (most } \\
\text { likely the root) }\end{array}$ \\
\hline
\end{tabular}

Figure 1. The flower of lenga, Sesamum indicum is one of the materia medica used for the treatment of eye disease in Ramuan Obat EAP153/9/4 ${ }^{19}$

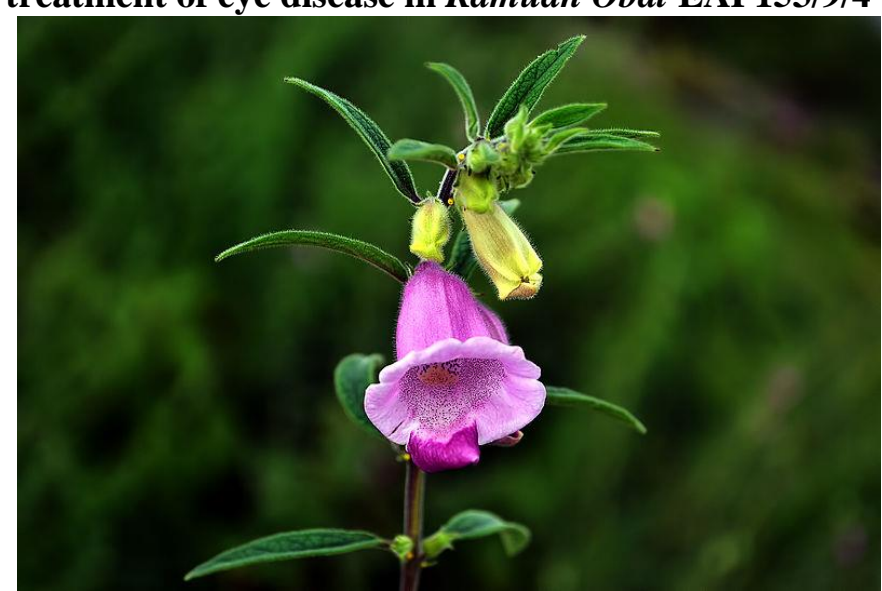

Figure 2. Peropok, Messua ferrea, which is rarely found mentioned in Malay medical manuscripts, is featured in Ramuan Obat EAP153/9/4 ${ }^{20}$

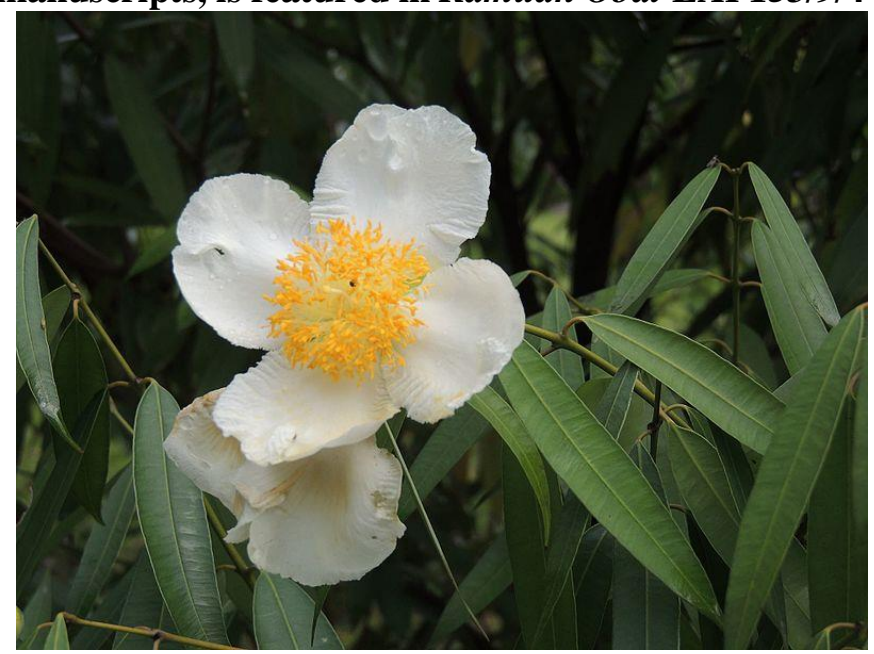

${ }^{19}$ Mullookkaaran, C.C. BY-SA $3.0<$ https://creativecommons.org/licenses/by-sa/3.0〉, via Wikimedia Commons.

${ }^{20} \mathrm{Johnsingh,} \mathrm{J.T.} \mathrm{WWF-India} \mathrm{and} \mathrm{NCF,} \mathrm{CC} \mathrm{BY-SA} 4.0<\mathrm{https}: / /$ creativecommons.org/licenses/by-sa/4.0>, via Wikimedia Commons. 
B. Animal-Based Materials

Table 4. The List of Identified Animal-/Human-Based Materials

\begin{tabular}{lll}
\hline Ingredients & Scientific Name & $\begin{array}{l}\text { Formulation Number } \\
(153 / 9 / 4 / F 0 x x)\end{array}$
\end{tabular}

\begin{tabular}{|c|c|c|c|}
\hline $\begin{array}{lll}\text { Ayam } & \text { hitam } \\
\text { (Cemani or } & \text { black } \\
\text { chicken) } & & \\
\text { (n) }\end{array}$ & $\begin{array}{lr}\text { Gallus } & \text { gallus } \\
\text { domesticus } & \text { Brisson }\end{array}$ & 153/9/4/F016 & Feather \\
\hline Kambing (Goat) & $\begin{array}{l}\text { Capra } \\
\text { hircus }\end{array}$ & 153/9/4/F009 & Gall bladder \\
\hline Lembu (Cow) & Bos taurus & 153/9/4/F017 & Flesh \\
\hline $\begin{array}{l}\text { Susu orang } \\
\text { belum bergigi }\end{array}$ & - & 153/9/4/F024 & Milk \\
\hline Susu & - & 153/9/4/F028 & Milk \\
\hline Kemih & - & 153/9/4/F028 & Urine \\
\hline
\end{tabular}

C. Miscellaneous

Table 5. The List of Identified Miscellaneous Materials

\begin{tabular}{|c|c|c|c|}
\hline Ingredient & Scientific Name & $\begin{array}{l}\text { Formulation Number } \\
(153 / 9 / 4 / F 0 x x)\end{array}$ & Forms Parts Used \\
\hline $\begin{array}{l}\text { Cuka masam } \\
\text { (Sour vinegar) }\end{array}$ & - & 153/9/4/F019 & Liquid \\
\hline Embun & - & 153/9/4/F028 & Dew \\
\hline Garam (Salt) & Sodium chloride & 153/9/4/F002 & Salt \\
\hline $\begin{array}{l}\text { Gula batu (Rock } \\
\text { sugar) }\end{array}$ & - & 153/9/4/F006 & Sugar \\
\hline Kasturi (Musk) & - & 153/9/4/F018 & Oil \\
\hline $\begin{array}{l}\text { Kayu arang } \\
\text { (Charcoal) }\end{array}$ & - & 153/9/4F005 & $\begin{array}{l}\text { Not stated (most } \\
\text { likely powder) }\end{array}$ \\
\hline Madu (Honey) & - & 153/9/4/F023 & Liquid \\
\hline Tawas (Alum) & Potassium alum & 153/9/4/F014 & Powder \\
\hline
\end{tabular}

Comparative Analysis of Materials Used

Comparative analysis was performed by comparing the medical content of the manuscript with modern scientific literature as a method of appraising the content of Ramuan Obat EAP153/9/4 manuscript. The comparative analysis is presented in Table 6 .

Table 6. Comparative Analysis of Materials and Modern Scientific Literature

\begin{tabular}{llll}
\hline $\begin{array}{l}\text { Formulation } \\
\text { Number } \\
(\mathbf{1 5 3 / 9 / 4 / F 0 x x})\end{array}$ & $\begin{array}{l}\text { Vernacular } \\
\text { Name }\end{array}$ & Scientific Name & Scientific Literature Evidence \\
\hline F001 & Afyun/Poppy & $\begin{array}{l}\text { Papaver } \\
\text { somniferum }\end{array}$ & $\begin{array}{l}\text { Preservation of Retina Ganglion } \\
\text { Cell Function by Morphine in a }\end{array}$ \\
& & $\begin{array}{l}\text { Chronic Ocular-Hypertensive } \\
\text { Rat Model (Husain, Abdul and } \\
\end{array}$ & \\
& & Crosson, 2012) \\
& & \\
\hline
\end{tabular}

${ }^{21}$ Shahid Husain, Yasir Abdul and Craig E. Crosson. (2012), "Preservation of Retina Ganglion Cell Function by Morphine in a Chronic Ocular-Hypertensive Rat Model," Investigative Opthalmology and Visual Science, Vol. 53, No. 7, p. 4289 


$\begin{array}{lll}\text { Limau Kapas } & \text { Citrus aurantifolia } & \text { Anticataractogenic effect of } \\ \text { (Key Lime) } & & \begin{array}{l}\text { hesperidin in galactose-induced } \\ \text { cataractogenesis in Wistar rats } \\ \text { (Manikandan and Arumugam, } \\ 2016)^{22}\end{array}\end{array}$

Minyak lenga

Sesamum indicum

(Sesame oil)

F002

F004

Kelor

Akar keremak

Kunyit

(Turmeric)

Buah Pala

(Nutmeg)

Limau Nipis

(Key Lime)

F005

Piper betle

Citrus aurantiifolia
Ipomea digitata

Curcuma longa

Myristica fragrans

Sepang

(Sappanwood)

Caesalpinia sappan

Kayu arang

(Charcoal)

Melur (Jasmine)

Protective Effect of Sesamo in the Selenite-induced Experimental Cataract Model (Turgut, Ergen and Ilhan, 2017) ${ }^{23}$ Effects of a new anti-allergic agent: the magnesium salt of $\mathrm{N}$ acetyl-aspartyl-glutamic acid on experimental allergic inflammation of the rabbit eye (Lapalus et al., 1986) ${ }^{24}$

Retinoprotective Effects of Moringa oleifera via Antioxidant, Anti-Inflammatory, and Anti-Angiogenic Mechanisms in StreptozotocinInduced Diabetic Rats (Gupta et al., 2013) $)^{25}$

Not Found

Inhibitory effect of curcumin on proliferation of human pterygium fibroblasts. (Zhang et al., 2007) $)^{26}$

Not Found

Anticataractogenic effect of hesperidin in galactose-induced cataractogenesis in Wistar rats (Manikandan and Arumugam, 2016) ${ }^{10}$

Not found

One-step isolation of sappanol and brazilin from Caesalpinia sappan and their effects on oxidative stress-induced retinal death (Uddin et al., 2015) ${ }^{27}$

Anti-inflammatory, antioxidant and antimicrobial activity of Ophthacare brand, an herbal eye drop (Mitra et al., 2000) ${ }^{28}$

Daya guna seduhan bunga melati (Jasminum Sambac)

\footnotetext{
${ }^{22}$ R. Manikandan et al. (2010), "Effect of Curcumin on Selenite-Induced Cataractogenesis in Wistar Rat Pups," Current Eye Research, Vol. 35, No. 2, pp. 122-129.

${ }_{23}$ Burak Turgut, B., Irfan Ergen and Nevin lihan (2017), "The Protective Effect of Sesamol in the Selenite-induced Experimental Cataract Model," Türk Oftalmoloji Dergisi, pp. 309-314.

${ }^{24}$ P. Lapalus et al. (1986), "Effects of a new anti-allergic agent: The magnesium salt of N-acetyl-aspartyl-glutamic acid on experimental allergic inflammation of the rabbit eye," Current Eye Research, Vol. 5, No. 7, pp. 517-522.

${ }^{25}$ Suresh Kumar Gupta et al. (2013), "Retinoprotective Effects of Moringa oleifera via Antioxidant, Anti-Inflammatory, and Anti-Angiogenic Mechanisms in Streptozotocin-Induced Diabetic Rats," Journal of Ocular Pharmacology and Therapeutics, Vol. 29, No. 4, pp. 419-426.

${ }^{26}$ Mingchang Zhang et al. (2007), "Inhibitory effect of curcumin on proliferation of human pterygium fibroblasts," Journal of Huazhong University of Science and Technology in Medical Science, Vol. 27, No. 3, pp. 339-42.

${ }^{27}$ Golam Mezbah Uddin et al. (2015), "One-step isolation of sappanol and brazilin from Caesalpinia sappan and their effects on oxidative stress-induced retinal death," BMB Reports, Vol. 48, No. 5, pp. 289-294.

${ }^{28}$ S. K. Mitra et al. (2000), "Anti-inflammatory, antioxidant and antimicrobial activity of Ophthacare brand, an herbal eye drops," Phytomedicine, Vol. 7, No. 2, pp. 123-127.
} 


\begin{tabular}{|c|c|c|c|}
\hline & Pucuk budi & Ficus beniamina & $\begin{array}{l}\text { dibandingkan dengan natrium } \\
\text { diklofenak } 1 \text { persen (Noncort) } \\
\text { tetes mata untuk mengurangi } \\
\text { hiperemia konjungtiva pada mata } \\
\text { kelinci (Abdan and Suhardjo, } \\
\text { 2014) } \\
\text { Not Found }\end{array}$ \\
\hline F006 & $\begin{array}{l}\text { Gula batu } \\
\text { (Rock Sugar) }\end{array}$ & - & Not Found \\
\hline F007 & $\begin{array}{l}\text { Asam Jawa } \\
\text { (Tamarind) }\end{array}$ & $\begin{array}{l}\text { Tamarindus } \\
\text { indica }\end{array}$ & $\begin{array}{l}\text { In Vitro Anticataract Activity of } \\
\text { Tamarindus Indica Linn. Against } \\
\text { Glucose-Induced } \\
\text { Cataractogenisis } \\
2018)^{30}\end{array}$ \\
\hline \multirow[t]{2}{*}{ F009 } & $\begin{array}{l}\text { Hempedu } \\
\text { Kambing } \\
\text { (Goat's Bile) }\end{array}$ & $\begin{array}{l}\text { Capra aegagrus } \\
\text { hircus }\end{array}$ & Not Found \\
\hline & $\begin{array}{l}\text { Lada Sulah } \\
\text { (Black Pepper) }\end{array}$ & Piper nigrum & $\begin{array}{l}\text { Antioxidant Effects of Piperine } \\
\text { In In-vivo Chick Embryo } \\
\text { Cataract Model Induced by } \\
\text { Steroids (Vurmaz et al., 2019) }\end{array}$ \\
\hline \multirow[t]{2}{*}{ F010 } & $\begin{array}{l}\text { Limau Kerbau } \\
\text { (Buffalo eye } \\
\text { citron) }\end{array}$ & Citrus medica & $\begin{array}{l}\text { An Expeditious Recovery from } \\
\text { Stye - A Case Study (Prakruthi et } \\
\text { al., 2018) }\end{array}$ \\
\hline & Garam (Salt) & Sodium chloride & $\begin{array}{l}\text { Effects of a new anti-allergic } \\
\text { agent: the magnesium salt of } \mathrm{N}- \\
\text { acetyl-aspartyl-glutamic acid on } \\
\text { experimental allergic } \\
\text { inflammation of the rabbit eye } \\
\text { (Lapalus et al., 1986) }^{12}\end{array}$ \\
\hline F011 & Penaga & Mesua ferrea $l$ & Not Found \\
\hline F012 & $\begin{array}{l}\text { Marapoyan/ } \\
\text { merpoyan }\end{array}$ & $\begin{array}{l}\text { Rhodamnia } \\
\text { cinerea }\end{array}$ & Not Found \\
\hline F013 & Ara tanah & Euphorbia hirta & $\begin{array}{l}\text { Effect of Euphorbia hirta in } \\
\text { Napthalene Induced Cataract in } \\
\text { Rats (Rathnakumar, Jaikumar } \\
\text { and Sengottuvelu, 2013) }\end{array}$ \\
\hline F014 & Sepang & $\begin{array}{l}\text { Caesalpinia } \\
\text { sappan }\end{array}$ & $\begin{array}{l}\text { One-step isolation of sappanol } \\
\text { and brazilin from Caesalpinia } \\
\text { sappan and their effects on } \\
\text { oxidative stress-induced retinal } \\
\text { death (Uddin et al., 2015) }{ }^{16}\end{array}$ \\
\hline
\end{tabular}


Tawas (Alum) Potassium alum

Comparative double-blind

randomized placebo-controlled clinical trial of a herbal eye drop formulation (Qatoor Ramad) of Unani medicine in conjunctivitis (Siddiqui, Zafar and Iqbal, 2002) $)^{34}$

F015 Kelumpang Sterculia spp.

Sterculic acid antagonizes 7ketocholesterol-mediated inflammation and inhibits choroidal neovascularization (Huang et al., 2012) (35 $^{35}$

F016

Bulu ayam hitam

Gallus gallus Not Found

(Black chicken domesticus

F017 feather)

F017

Daging lembu Bostaurus

Not Found

(Beef)

Cabai

Piper longum

Mechanism of capsaicin inhibition of aldose reductase activity (Alim et al., 2016) (36 $^{36}$

Ursi

Unidentified N/A

Terung (Eggplant)

F018 Kelumpang

Solanum spp.

Not Found

Sterculia spp.

Sterculic acid antagonizes 7ketocholesterol-mediated inflammation and inhibits choroidal neovascularization (Huang et al., 2012) ${ }^{24}$

\section{Kasturi (Musk) -}

Not Found

F019

Bilang-bilang

Sesuvium

Not Found

portulacastrum

Cuka masam

(Sour vinegar)

F020

Anjan-anjan

putih

F021

Bayam

(Spinach)

Mawar (Rose)

$-$

Not Found

Paji

Memecylon

Not Found

umbellatum

Amaranthus spp. Not Found

Anjan-anjan

putih

Rosa spp.

Not Found

F022

Drybalanops

Not Found

lanceolata

Not Found

Paji

umbellatum

Drybalanops

Not Found

Cuka masam lanceolata

F023

(Sour Vinegar)

Peropok

Hemigyrosa

longifolia

Not Found

Not Found

Madu (Honey)

A Double-Blind Clinical Trial on

\footnotetext{
34 T. A. Siddiqui, T. S. Zafar and N. Iqbal (2002), "Comparative double-blind randomized placebo-controlled clinical trial of a herbal eye drop formulation (Qatoor Ramad) of Unani medicine in conjunctivitis,” Journal of Ethnopharmacology, Vol. 83, No. 1-2, pp. 13-17.

35 Jiahn-Dar Huang et al. (2012), "Sterculic acid antagonizes 7-ketocholesterol-mediated inflammation and inhibits choroidal neovascularization," Biochimica Et Biophysica Acta (BBA) - Molecular and Cell Biology of Lipids, Vol. 1821, No. 4, pp. 637-646.

${ }^{36}$ Zuhal Alim et al. (2017), "Mechanism of capsaicin inhibition of aldose reductase activity," Journal of Biochemical and Molecular Toxicology, Vol. 31, No. 7.
} 


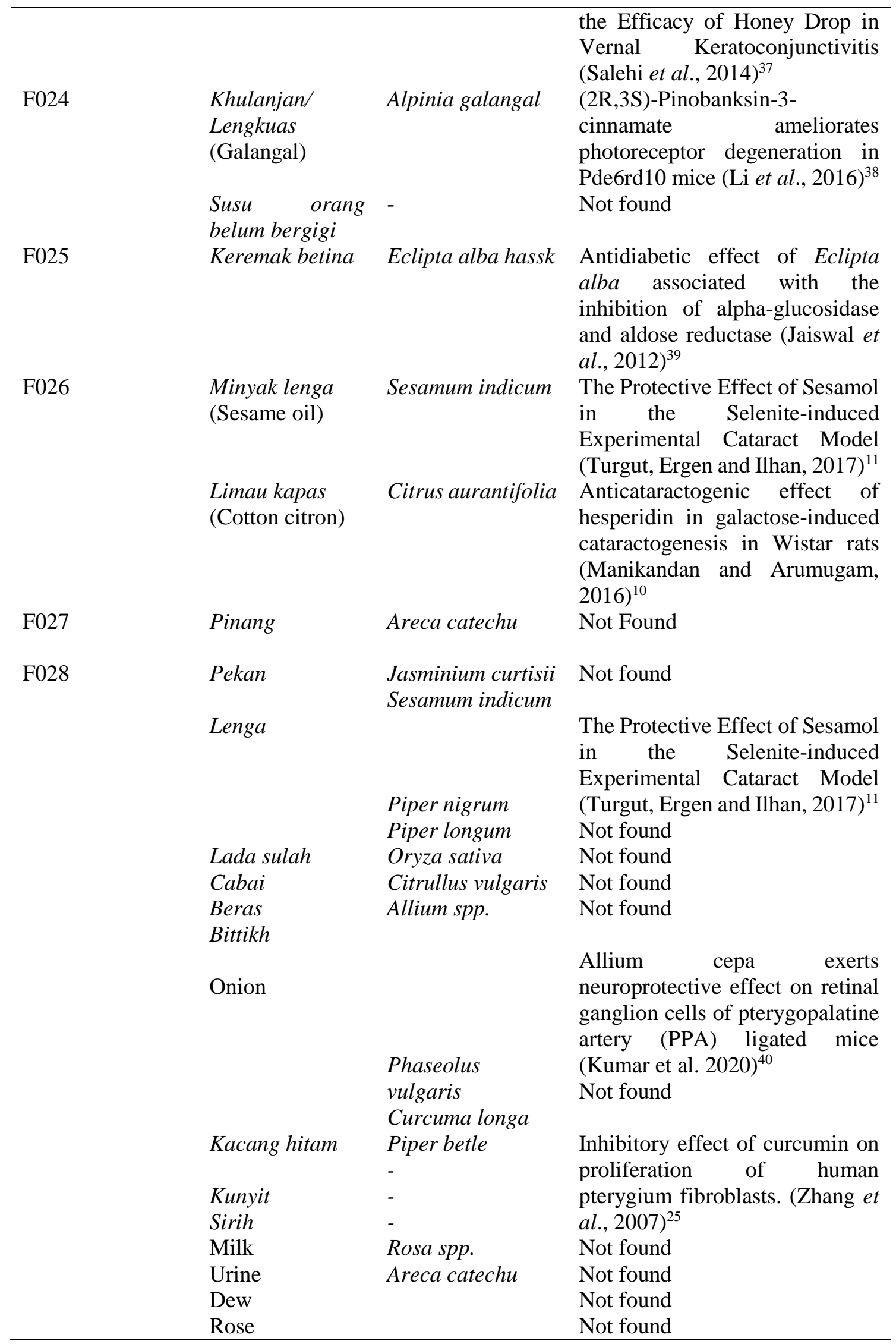

\footnotetext{
${ }^{37}$ Ali Salehi et al. (2014), "A Double Blind Clinical Trial on the Efficacy of Honey Drop in Vernal Keratoconjunctivitis," Evidence-Based Complementary and Alternative Medicine, pp. 1-4.

${ }^{38}$ Yin Li et al. (2016), "(2R, 3S)-Pinobanksin-3-cinnamate ameliorates photoreceptor degeneration in Pde6rd10 mice," Cutaneous and Ocular Toxicology, Vol. 36, No. 3, pp. 273-277.

${ }^{39}$ Natasha Jaiswal et al. (2012), "Antidiabetic effect of Eclipta alba associated with the inhibition of alpha-glucosidase and aldose reductase," Natural Product Research, Vol. 26, No. 24, pp. 2363-2367.

${ }^{40}$ Saurabh Kumar et al. (2020), "Allium cepa exerts neuroprotective effect on retinal ganglion cells of pterygopalatine artery (PPA) ligated mice," Journal of Ayurveda and Integrative Medicine, Vol. 11, No. 4, pp. 489-494.
} 


Pinang Not found

Not found

\section{Discussion}

Based on the transliteration of the Ramuan Obat EAP153/9/4, a total of 28 formulations were identified. The formulations can be further divided into a few categories namely formulations that utilize herbs or materials alone, followed by the second category which is the formulations that utilized herbs or materials supported by prayers. The third category of the formulation identified is the utilization of prayers alone and the final category involves incomplete formulation. 20 formulations are found to be in the first category, followed by 5 formulations that belong in the second category and 2 formulations in the third category. There is only 1 incomplete formulation i.e. the first formulation. This is due to the fact that the previous page that carries the rest of the formulation was found missing. This finding also raises the possibility that the manuscript is part of a larger, more complete text on eye disease, or even bodily system. This is however difficult to ascertain unless the other missing portions are available.

It can be observed that the traditional Malay medical practices as portrayed in Ramuan Obat EAP153/9/4 comprised of both physical and spiritual elements. The physical element is shown by the use of materials such as herbs and animals. The spiritual element on the other hand, is shown through the sole use or incorporation of prayers in the process of treatment as can be seen in some formulations such as 153/9/4F003, 153/9/4/F008 and 153/9/4/F028. The prayers in question comprised of salawāt, fragments of Quranic verses and prayer from the Prophet Muhammad (SAW). It is noticeable that the essence of the prayers incorporated mainly revolves around eyes which makes their use for the treatment of eye diseases relevant. For example, as in formulation 153/9/4/F003, the use of the verse 66 of Surah

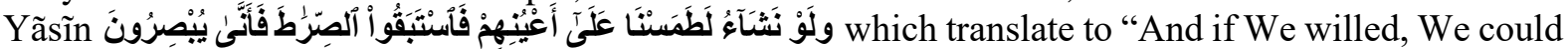
have obliterated their eyes, and they would race to [find] the path, and how could they see?" 41 Another

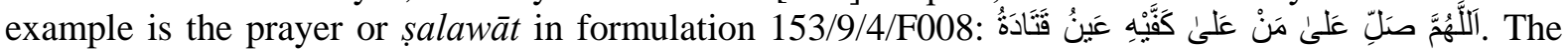
history behind the prayer involved one of the Prophet's companions, Qatadah bin al-Nu'man whose eye was pierced by an arrow during the battle of Uhud, resulting in one of his eyeballs to be dislodged its the socket. In the event, Prophet Muhammad SAW went to him and put the dislodged eye back into its place. It quickly recovered and became Qatadah's best eye. ${ }^{42}$ The origin of the salawāt is unknown. It appears to have been formulated post-Prophet time. The use of Quranic verse, salawāt or prayers in healing practices reflects the Islamic influence on the old Malay civilisation in the Archipelago and work to enhance healing effects of formulation or have healing property on its own.

The plant-based materials nevertheless form the dominant part of the manuscripts with only a few materials are probably from abroad such as anjan-anjan (Memecylon umbellatum) and afyun (Papaver somniferum). The other plants are native plants of the Malay Archipelago which are commonly found in other Malay medical manuscripts, though whether the plants and other materia medica as well as each formulation is also used as eye treatments in the other Malay medical manuscripts would require a separate study. The use of specifically Malay lexicals such as ayam cemani (black chicken) and specifically Malay taxonomy, such as keremak betina (Eclipta alba hassk) in Ramuan Obat EAP $153 / 9 / 4$ indicate that the medical knowledge in this manuscript is essentially Malay in nature, enriched with influences that came via trade routes and Islam.

The analysis performed on the extracted data identified a total of 49 different materials which are further classified into plant-based materials, animal-based materials and miscellaneous. Half of the materials mentioned in the Ramuan Obat EAP 153/9/4 manuscript in the treatment of eye diseases have some supportive evidence from contemporary clinical or scientific evidence, whereas the other half of the materials are yet be supported by scientific evidence in their abilities to treat eye diseases (Table 6). It is important to note that the current unavailability of scientific support does not immediately discount the potential of these materials as these could be due to limitations in search strategy and complete absence of research on the materials as eye treatments. Therefore, this calls for more scientific clinical studies to be carried out with regard to Malay medical manuscripts.

\footnotetext{
${ }^{41}$ Quran.com (2016), Surah Ya-Sin [36:66] al-Qur'an al-Kareem. Accessed September 3, 2020, https://quran.com/36/66.

42 Mohammed Reda (2013), Mohamed the Messenger of Allah: إذ كل يزي] (ص) الله ر سول محمد, Beirut: Dar Al-Kotob al-Ilmiyah, p. 365.
} 


\section{Conclusion}

The study of the Malay medical manuscript Ramuan Obat EAP153/9/4 showed that the medical practices of the Malay civilisation comprised of both physical and spiritual elements as portrayed by the use of materials (physical element) and the incorporation of prayer as the spiritual elements. In terms of scientific values, half of the materials identified in the text of Ramuan Obat EAP153/9/4 manuscript are supported by clinical scientific evidence with regard of treating eye diseases and as more scientific studies are carried out, the gap between the verified and unverified contents of the manuscript can be closed.

\section{References}

Abdan, A., and Suhardjo, H. (2007), "Daya guna seduhan bunga melati (Jasminum Sambac) dibandingkan dengan natrium diklofenak 1 persen (Noncort) tetes mata untuk mengurangi hiperemia konjungtiva pada mata kelinci," Doctoral dissertation, Gadjah Mada University.

Abdul Ghani Hussain (2015), MSS2999 Kitab Tib: Pandangan dan Tafsiran Perubatan Moden Terhadap Manuskrip Perubatan Melayu, Kuala Lumpur: Institut Penyelidikan Perhutanan Malaysia.

Abdul Ghani Hussain (2019), Dermatologi Dalam Kitab Tib Muzium Terengganu, Kuala Lumpur: Institut Penyelidikan Perhutanan Malaysia.

Ab. Razak Abdul Karim (2006), Analisis Bahasa Dalam Kitab Tib Pontianak, Kuala Lumpur: Dewan Bahasa dan Pustaka.

Alim, Z., Kilinc, N., Sengul, B., and Beydemir, S. (2017), "Mechanism of capsaicin inhibition of aldose reductase activity," Journal of Biochemical and Molecular Toxicology, Vol. 31, No. 7.

Amalia, H., Sitompul, R., Hutauruk, J., Andrianjah, and Abdul Mun'im. (2009), "Effectiveness of Piper betle leaf infusion as a palpebral skin antiseptic," Universa Medicina, Vol. 28, No. 2, 83-91.

Gupta, S. K., Kumar, B., Srinivasan, B., Nag, T. C., Srivastava, S., Saxena, R., and Aggarwal, A. (2013), "Retinoprotective Effects of Moringa oleifera via Antioxidant, Anti-Inflammatory, and AntiAngiogenic Mechanisms in Streptozotocin-Induced Diabetic Rats," Journal of Ocular Pharmacology and Therapeutics, Vol. 29, No. 4, 419-426.

Harun Mat Piah (2015), "Ilmu Perubatan Melayu Tradisional dari Naskhah-Naskhah Lama," Jurnal Antarabangsa Alam Dan Tamadun Melayu, Vol. 3, No.3, 3-17.

Harun Mat Piah and Zawiyah Baba (2014), Kitab Tib MSS2515, Bangi: Penerbit UKM.

Harun Mat Piah (2017), Kitab Tib Muzium Terengganu, Kuala Lumpur: Institut Penyelidikan Perhutanan Malaysia.

Harun Mat Piah and Nik Musa'adah Mustapha (2019), Kitab Tib MSS1292, Kuala Lumpur: Institut Penyelidikan Perhutanan Malaysia.

Huang, J., Amaral, J., Lee, J. W., Larrayoz, I. M., and Rodriguez, I. R. (2012), "Sterculic acid antagonizes 7-ketocholesterol-mediated inflammation and inhibits choroidal neovascularization," Biochimica Et Biophysica Acta (BBA) - Molecular and Cell Biology of Lipids, Vol. 1821, No. 4, 637646.

Husain, S., Abdul, Y., and Crosson, C. E. (2012), "Preservation of Retina Ganglion Cell Function by Morphine in a Chronic Ocular-Hypertensive Rat Model," Investigative Opthalmology and Visual Science, Vol. 53, No.7, 4289-4298.

Indirawati Zahid, Ab Razak Ab Karim and Rohaidah Haron (2019), "Kata Kerja dan Komunikasi Berkesan Dalam Kitab Tib Muzium Terengganu dan Huraian Teks," Bitara: International Journal of Civilisational Studies and Human Sciences, Vol. 2, No. 4, 27-42. 
Jaiswal, N., Bhatia, V., Srivastava, S. P., Srivastava, A. K., and Tamrakar, A. K. (2012), "Antidiabetic effect ofEclipta albaassociated with the inhibition of alpha-glucosidase and aldose reductase," Natural Product Research, Vol. 26, No. 24, 2363-2367.

John D. Gimlette and H.W. Thomson (1939), A Dictionary of Malayan Medicine, London: Oxford University Press.

Kumar,S., Modgil, S., Bammidi, S., Minhas, G., Shri, R., Kaushik, S., Singh, V. and Anand, A. (2020 "Allium cepa exerts neuroprotective effect on retinal ganglion cells of pterygopalatine artery (PPA) ligated mice." Journal of Ayurveda and Integrative Medicine, Vol. 11, No. 4, 489-494.

Lapalus, P., Moulin, G., Bayer, V., Fredj-Reygrobellet, D., and Elena, P. P. (1986), "Effects of a new anti-allergic agent: The magnesium salt of $\mathrm{N}$-acetyl-aspartyl-glutamic acid on experimental allergic inflammation of the rabbit eye," Current Eye Research, Vol. 5, No.7, 517-522.

Li, Y., Li, T., Li, J., and Wu, Q. (2016), “(2R, 3S)-Pinobanksin-3-cinnamate ameliorates photoreceptor degeneration in Pde6rd10 mice," Cutaneous and Ocular Toxicology, Vol. 36, No. 3, 273-277.

Manikandan, R., Thiagarajan, R., Beulaja, S., Sudhandiran, G., and Arumugam, M. (2010), "Effect of Curcumin on Selenite-Induced Cataractogenesis in Wistar Rat Pups," Current Eye Research, Vol. 35, No. 2, 122-129.

Merugu, S. (2009), "In Vitro Anticataract Activity of Tamarindus Indica Linn. Againest GlucoseInduced Cataractogenisis," Doctoral dissertation, Sri Ramakrishna Institute of Paramedical Sciences, Coimbatore.

Mitra, S., Sundaram, R., Venkataranganna, M., Gopumadhavan, S., Prakash, N., Jayaram, H., and Sarma, D. (2000), "Anti-inflammatory, antioxidant and antimicrobial activity of Ophthacare brand, an herbal eye drops," Phytomedicine, Vol. 7, No. 2, 123-127.

Mohammed Reda (2013), Mohammed the Messenger of Allah: إذ كل يزي] (ص) الله ر سول محمد, Beirut: Dar Al-Kotob Al-Ilmiyah.

Mohd Affendi Mohd Shafri (2018), Rumah Ubat Di Pulau Penyengat, Kuala Lumpur: Akademi Jawi Malaysia Sdn Bhd.

Mohd Affendi Mohd Shafri (2019), Sari Segala Ubat, Kuala Lumpur: Akademi Jawi Malaysia Sdn Bhd. Mohd Affendi Mohd Shafri (2015), Tayyib al-Ihsan fi al-Tibb al-Insan, Kuala Lumpur: Akademi Jawi Malaysia.

Mohd Affendi Mohd Shafri (2017), al-Rahmah fi al-Tib wa al-Hikmah, Kuala Lumpur: Akademi Jawi Malaysia.

Muhammad Widus Sempo, Nazariah Yahya, Malki Ahmad Nasir and Mohd Azmi Mohd Razif, Rawatan Sakit Cacingan dalam Manuskrip Perubatan Melayu, Kuala Lumpur: Penerbit USIM.

Prakruthi, G., Shaw, S. K., Hamsaveni, V. K., and Sujathamma, K. K. (2018), "An Expeditious Recovery from Stye - A Case Study,” Delhi Journal of Ophthalmology, Vol. 29, No. 2, 61-64.

Quran.com (2016), Surah Ya-Sin [36:66] al-Qur'an al-Kareem. Accessed September 3, 2020, https://quran.com/36/66.

Rathnakumar, K., Jaikumar, S., and Sengottuvelu, S. (2013), "Effect of Euphorbia hirta in Napthalene Induced Cataract in Rats [Abstract]," Research Journal of Pharmacy and Technology, Vol. 6, No. 8, 908-911. 
Salehi, A., Jabarzare, S., Neurmohamadi, M., Kheiri, S., and Rafieian-Kopaei, M. (2014), "A DoubleBlind Clinical Trial on the Efficacy of Honey Drop in Vernal Keratoconjunctivitis," Evidence-Based Complementary and Alternative Medicine, 1-4.

Siddiqui, T., Zafar, S., and Iqbal, N. (2002), "Comparative double-blind randomized placebo-controlled clinical trial of a herbal eye drop formulation (Qatoor Ramad) of Unani medicine in conjunctivitis," Journal of Ethnopharmacology, Vol. 83, No. 1-2, 13-17.

$\mathrm{Tu}, \mathrm{Y}$. (2011), "The discovery of artemisinin (qinghaosu) and gifts from Chinese medicine," Nature Medicine, Vol. 17, No.10, 1217-1220.

Turgut, B., Ergen, I., and Ilhan, N. (2017), "The Protective Effect of Sesamol in the Selenite-induced Experimental Cataract Model," Türk Oftalmoloji Dergisi, 309-314.

Uddin, G. M., Kim, C. Y., Chung, D., Kim, K., and Jung, S. H. (2015), "One-step isolation of sappanol and brazilin from Caesalpinia sappan and their effects on oxidative stress-induced retinal death," $B M B$ Reports, Vol. 48, No.5, 289-294.

Vurmaz, A., Duman, R., Sabaner, M. C., Ertekin, T., and Bilir, A. (2019), "Antioxidant effects of piperine in in-vivo chick embryo cataract model induced by steroids," Cutaneous and Ocular Toxicology, Vol. 38, No. 2, 182-189.

Zhang, M., Bian, F., Wen, C., and Hao, N. (2007), 'Inhibitory effect of curcumin on proliferation of human pterygium fibroblasts." Journal of Huazhong University of Science and Technology in Medical Science, Vol. 27, No. 3, 339-42. 
Journal of Al-Tamaddun, Vol. 16 (1), 2021, 27-45 